\title{
THE AVAILABILITY OF ANTIHYPERTENSIVE DRUG IN ERA OF NHI: A STUDY IN THE PRIMARY HEALTH CARE CENTRE JAKARTA-INDONESIA
}

\section{MITA RESTINIA $^{1}$, DIAN RATIH LAKSMITAWATI ${ }^{1}$, YUSI ANGGRIANI ${ }^{1}$, YUDHA SEKOWATI ${ }^{2}$}

1Faculty of Pharmacy, Pancasila University, Jakarta 12640, Indonesia, ${ }^{2}$ Academy Pharmacy IKIFA, Jakarta, Indonesia

*Email: mita_restinia@univpancasila.ac.id

Received: 06 Sep 2020, Revised and Accepted: 08 Oct 2020

\section{ABSTRACT}

Objective: The study was carried out to observe the impact of NHI to availability, usage, stock of antihypertensive drug enrolled in a national formulary in one of the primary health care centre in Jakarta.

Methods: A longitudinal time series design was performed retrospectively to analyse the availability, usage, and stock of antihypertensive drug. The data period was from January 2013 (1 y before NHI) to December 2015 (2 y after NHI). The Independent-Samples T or Mann-Whitney test was conducted to compare these parameters before and after NHI.

Results: We found amlodipine $5 \mathrm{mg}$ and $10 \mathrm{mg}$ tablet, hydrochlorothiazide $25 \mathrm{mg}$ tablet, captopril $12.5 \mathrm{mg}$ and $25 \mathrm{mg}$ tablet, nifedipine $10 \mathrm{mg}$ tablet were available in Primary Health Care. These drug were generic and tablet dosage form. The most common drug used was captopril and Nifedipine, respectively. The highest availability was diuretic hydrochlorothiazide. The availability of amlodipine $5 \mathrm{mg}$ and $10 \mathrm{mg}$ tablet, captopril $12.5 \mathrm{mg}$ tablet increased significantly $(\mathrm{P}<0.05)$ after NHI was implemented. Moreover, hydrochlorothiazide decreased $(\mathrm{P}<0.05)$ as well. The usage of amlodipine and hydrochlorothiazide risen $(\mathrm{P}<0.05)$ but the nifedipine decreased $(\mathrm{P}<0.05)$ after NHI. All stock of antihypertensive except captopril $25 \mathrm{mg}$ different significantly $(\mathrm{P}<0.05)$ after the application of $\mathrm{NHI}$

Conclusion: This study highlights the implementation of NHI impacted the availability, usage, and stock of antihypertensive drug enrolled in national formulary.

Keywords: NHI, Drug availability, Drug used, Drug stock, Antihypertensive drug

(C) 2021 The Authors. Published by Innovare Academic Sciences Pvt Ltd. This is an open access article under the CC BY license (http://creativecommons.org/licenses/by/4.0/) DOI: http://dx.doi.org/10.22159/ijap.2021.v13s2.18 Journal homepage: https://innovareacademics.in/journals/index.php/ija

\section{INTRODUCTION}

The Indonesian government implemented National Health Insurance (NHI) known as Jaminan Kesehatan Nasional (JKN) on $1^{\text {stJanuary }}$ 2014. The aim of its implementation was to increase access and improve the quality of healthcare for Indonesian citizen [1]. In era of NHI in Indonesia, health policy has reformed, mainly the payment method, medicine utilization policy, and procurement.

The government changed the payment method from fee for service (FFS) to the Indonesian Case Base Group (Ina-CBGs) payment method. Ina-CBG was system for classifying patient care adopted by Drug Related Group (DRG). All treatment services, including medicines, were covered by insurance with FFS payment method. However, the payment method of Ina-CBGs limited covered of treatment cost regarding on package rate of diagnose [2]. The package rate of Ina-CBGs compose the cost of doctor, administration, medical examination, laboratory tests, and medicines. The package rate for one patient's different based on type and place of health care services [3]

The guideline for utilization of medicine was different before and after NHI. Before the implementation of NHI, the public health care center requested the drug based on plafond list of price drug known as Daftar Plafon Harga Obat (DPHO) [4]. Meanwhile, in era of NHI the public health care center should demand appropriate drug based on National Formulary [5]. Therefore, the demand of National Formulary medicine will be increase.

National Formulary contains the list of drug has created by government and improved continuously, mainly the prices of drug. The prices of National Formulary medicines are regulated under Presidential Decree No. 111 of 2013 [6]. The list of medicine in National Formulary were generic. The different finding in DPHO, there were available branded and generic drug. In Mexico, after the implementation of universal health coverage (UHC), the usage of generic increased and $17.3 \%$ patients did not get the medicine due to the limitation of drug availability [7]. Another studyIn Sudan, medicine usage increased significantly after the implementation of UHC [8] and the similar result found in Korea [9].

Another health policy reformed after NHI implementation was the procurement. In era of NHI, the procurement of National Formulary medicine is limited by e-catalogue [10]. All public health care centers access e-catalogue online through an online link (https://e-katalog. lkpp. go. id/). Meanwhile, there is no limitation access to procure the medicine before $\mathrm{NHI}$

Hypertension is one of chronic disease require long treatment and medicine. The availability of antihypertensive is one of parameter to support the success of treatment. National health survey (2014) in Indonesia showed the prevalence of hypertension was $25.8 \%$. This percentage increased compare to the previous. The $20 \%$ people in metropolitan city in Indonesia have diagnosed hypertension [11].

There are 24 antihypertensive drugs enrolled in National Formulary [5]. These drugs are divided some dosage forms, such as tablet, film coated tablet, extended coated tablet, injection, infusion. The list of drug in National Formulary generally consisted the drug choice for hypertention. The first choice antihypertensive by JNC 8 and European Society of Hypertension (ESH) and of the European Society of Cardiology (ESC) the guideline for hypertension were angiotensin-converting enzyme (ACEI), such as captopril, Angiostensin receptor blocker (ARB) as valsartan, Ca channel blocker (CCB) as amlodipine and nifedipine, and diuretic hydrochlorothiazide $[12,13]$.

The health care facilities in Indonesia are divided to the first health care centre, such as primary health care and secondary health care. All member of NHI should visit firstly to primary health care to heal the ailment. Furthermore, the disease was not improved in primary health care; the patients refer to higher health care facilities. The patients are not allowed directly to secondary health care centre. After NHI was implemented, the number of patients visit to the primary health care center increase significantly. In addition, the research on impact of NHI in primary healt care sites of Indonesia 
are limited. Therefore this study was carried out to analyse the impact of NHI to the availability, usage, and stock of antihypertensive drug in primary health care centre in metropolitan city in Jakarta, Indonesia.

\section{MATERIALS AND METHODS}

\section{Materials}

The planning drug supply book, the report of drug used and drug demand, drug stock card, drug demand and supply book, DPHO 2011, and National Formulary were the data source in this study.

\section{Study design}

The availability of antihypertensive drug, drug used, and stock of drug was observed by longitudinal time series design study. The period of data was followed retrospectively was 2013 (1 y before $\mathrm{NHI}$ ) to 2015 (2 y after $\mathrm{NHI}$ ).

\section{Inclusion and exclusion criteria}

All antihypertensive drug found in National Formulary were included in this study. The uncompleted data of availability, usage, and stock of antihypertensive drug during data period (January 2013 to December 2015) were excluded.

\section{Study indicators}

Each indicator was analyzed based on the period before and after the implementation of the NHI. These indicators are as follows: the percentage drug used per availability of antihypertensive drug, the availability antihypertensive drug, the usage of antihypertensive drug, and the stock of antihypertensive drug.

\section{Analysis of data}

The statistical analysis was used to understand the different all parameters between before and after NHI. The data normally distributed was analysed by Independent-Samples T test. MannWhitney test was used to analyse the non-normal distribution data.

\section{RESULTS}

\section{The percentage of drug used (U) and availability (A)}

Table 1 showed that the highest availability antihypertensive drug in primary health care centre in Jakarta was hydrochlorothiazide tablet (tab) $25 \mathrm{mg}$ and was followed nifedipine tab $10 \mathrm{mg}$, captopril tab $12.5 \mathrm{mg}$ respectively. Meanwhile, the most frequent antihypertensive drug used $(\% \mathrm{U} / \mathrm{A})$ was not the highest available. Captopril and nifedipine $10 \mathrm{mg}$ were the most frequent used. The percentage of drug used and the availability increased after $\mathrm{NHI}$ from $23.12 \%$ to $31.14 \%$.

Table 1: The average of the availability (A) and drug used (U) of antihypertensive drug

\begin{tabular}{|c|c|c|c|c|c|c|c|c|c|}
\hline \multirow[t]{2}{*}{ Kind of medicine } & \multicolumn{3}{|c|}{1 y before NHI (strip/blister) } & \multicolumn{3}{|c|}{1 y after NHI (strip/blister) } & \multicolumn{3}{|c|}{2 y after NHI (strip/blister) } \\
\hline & A & $\mathbf{U}$ & $\%$ U/A & A & $\mathbf{U}$ & $\%$ U/A & A & $\mathbf{U}$ & $\% \mathrm{U} / \mathrm{A}$ \\
\hline HCT tab $25 \mathrm{mg}$ & 4154.42 & 144.58 & 3 & 3068.75 & 292.33 & 10 & 1855.5 & 251.67 & 14 \\
\hline Nifedipine tab $10 \mathrm{mg}$ & 2620.58 & 606.83 & 23 & 3210.5 & 522.00 & 16 & 1667.25 & 202.92 & 12 \\
\hline Captopril tab $12.5 \mathrm{mg}$ & 2447.42 & 1179.25 & 48 & 3068.75 & 1147.00 & 37 & 3560.83 & 1167.25 & 33 \\
\hline Captopril tab $25 \mathrm{mg}$ & 2345.00 & 728.92 & 31 & 3497.42 & 1046.42 & 30 & 1540.17 & 543.67 & 35 \\
\hline Amlodipine tab 5 mg & 216.00 & 64.83 & 30 & 566.25 & 262.42 & 46 & 1327.25 & 892.42 & 67 \\
\hline Amlodipine tab $10 \mathrm{mg}$ & & & & & & & 478.67 & 189.92 & 40 \\
\hline Total & 11783.42 & 2724.41 & 23.12 & 13411.67 & 3270.17 & 24.38 & 10429.67 & 3247.83 & 31.1 \\
\hline
\end{tabular}

\section{The statistical analysis}

Table 2 showed the result of statistical analysis of the different availability, usage, and stock of antihypertensive drug between before and after NHI in the primary health care centre site. The availability, usage and the stock of amlodipine $5 \mathrm{mg}$ tab increased significantly $(\mathrm{P}<0.05)$. Meanwhile, there was no prescribed amlodipine $10 \mathrm{mg}$ tab before NHI. The availability and stock of hydrochlorothiazide decreased $(\mathrm{P}<0.05)$ eventhough this medicine prescribed wisely after NHI. The increased of this medicine was not proportional with the availability and stock. Therefore, the availability and stock of hydrochlorothiazide were dropped after NHI. The availability and stock of captoprile $12.5 \mathrm{mg}$ raised significantly $(\mathrm{P}<0.05)$. The different finding with the usage of this medicine was not different between before and after NHI. Captopril $25 \mathrm{mg}$ tab was not different statistically related its availability, usage and stock $(\mathrm{P}>0.05)$. Nifedipine tab was prescribed not frequent after NHI. Therefore the stock of increased significantly $(\mathrm{P}<0.05)$.

Table 2: The statistical analysis availability, usage, and stock of antihypertensive drug

\begin{tabular}{|c|c|c|c|}
\hline Indicators & Mean \pm SD Before NHI & Mean \pm SD After NHI & Sig (2 Tailed) \\
\hline \multicolumn{4}{|l|}{ Amlodipine $5 \mathrm{mg}$ tab } \\
\hline The availability & $216 \pm 91.781$ & $946.75 \pm 576.057$ & $0.000^{* *}$ \\
\hline The usage & $64.83 \pm 54.891$ & $577.42 \pm 424.586$ & $0.000^{* *}$ \\
\hline The stock & $151.58 \pm 104.531$ & $406.83 \pm 249.090$ & $0.002^{* *}$ \\
\hline \multicolumn{4}{|l|}{ Amlodipine $10 \mathrm{mg}$ tab } \\
\hline The availability & $0.00 \pm 0.00$ & $239.33 \pm 333.992$ & $0.011^{* *}$ \\
\hline The usage & $0.00 \pm 0.00$ & $94.96 \pm 119.321$ & $0.011^{* *}$ \\
\hline The stock & $0.00 \pm 0.00$ & $144.79 \pm 240.606$ & $0.027^{* *}$ \\
\hline \multicolumn{4}{|c|}{ Hydrochlorothiazide $25 \mathrm{mg}$ tab } \\
\hline The availability & $4154.42 \pm 717.772$ & $2462.13 \pm 1091.812$ & $0.000^{* *}$ \\
\hline The usage & $144.58 \pm 56.784$ & $272.00 \pm 136.315$ & $0.002^{* *}$ \\
\hline \multirow{2}{*}{\multicolumn{4}{|c|}{ Captoprile $12.5 \mathrm{mg}$ tab }} \\
\hline & & & \\
\hline The availability & $2447.42 \pm 776.251$ & $3529.13 \pm 1107.737$ & $0.005^{*}$ \\
\hline The usage & $1179.25 \pm 222.796$ & $1157.13 \pm 337.424$ & $0.402^{* *}$ \\
\hline The stock & $1461.50 \pm 621.854$ & $2360.75 \pm 1063.083$ & $0.011^{*}$ \\
\hline Captoprile $25 \mathrm{mg}$ tab & $2345 \pm 568.659$ & $2375.33 \pm 1334.003$ & $0.638^{* *}$ \\
\hline The availability & $728.92 \pm 227.950$ & $795.04 \pm 355.189$ & $0.840^{* *}$ \\
\hline The usage & $1616.08 \pm 628.445$ & $1579.04 \pm 1107.668$ & $0.568^{* *}$ \\
\hline \multicolumn{4}{|l|}{ The stock } \\
\hline Nifedipine $10 \mathrm{mg}$ tab & $1787.25 \pm 426.446$ & $1922.50 \pm 687.280$ & $0.856^{* *}$ \\
\hline The availability & $606.83 \pm 255.727$ & $362.46 \pm 242.887$ & $0.008^{*}$ \\
\hline The usage & $1181.92 \pm 409.925$ & $1560 \pm 523.245$ & $0.036^{*}$ \\
\hline
\end{tabular}

Before: the period before was January to December 2013. After: the period after was January 2014 to December 2015. *Independent-Samples T test and ${ }^{* *}$ Mann-Whitney test. ( $\left.\mathrm{P}=95 \%\right)$ 
The impact of NHI to the availability, usage, and stock of antihypertensive drug hydrochlorothiazide tab $25 \mathrm{mg}$

The availability and stock of hydrochlorothiazide in the end of $1 \mathrm{y}$ before NHI tend to be decrease until the first quarter year the implementation of NHI (fig. 1). The different result was found in the second quarter in the first-year implementation of $\mathrm{NHI}$, the availability increased significantly until September 2014 and tend to be decrease in the lowest availability. Furthermore, the usage of this drug slightly increased after NHI implementation because the number of patients visit the primary health care centre increased as well. The statistical analysis showed the availability and stock of drug decreased significantly $(\mathrm{P}<0.05)$.

\section{Nifedipine tab 15 mg}

Nifedipine tab $15 \mathrm{mg}$ was the second-highest available antihypertensive drug in the primary health care centre in Jakarta. Fig. 2 showed the available and stock of nifedipine rise significantly in the first semester $\mathrm{NHI}$ implemented and then fluctuated decrease and became stable in the second year of NHI. Furthermore, the usage of this tablet was not different between before and $1 \mathrm{y}$ after NHI but slightly decreased after NHI.

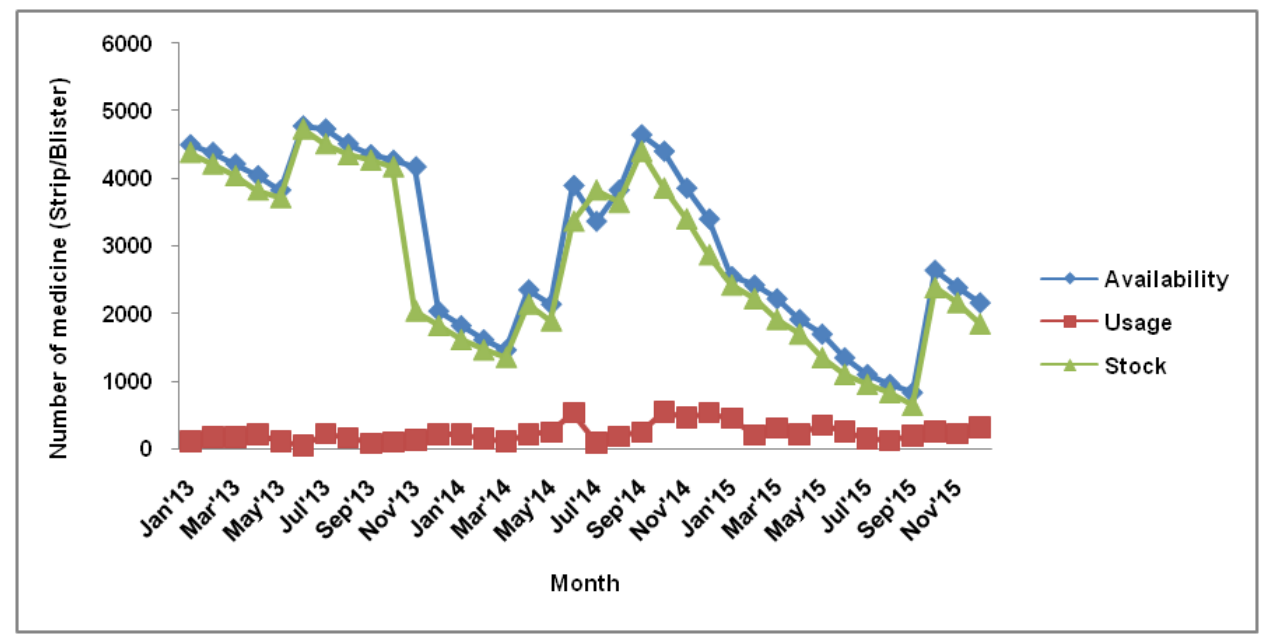

Fig. 1: Trend of the availability, usage, stock of hydrochlorothiazide tab 25 mg

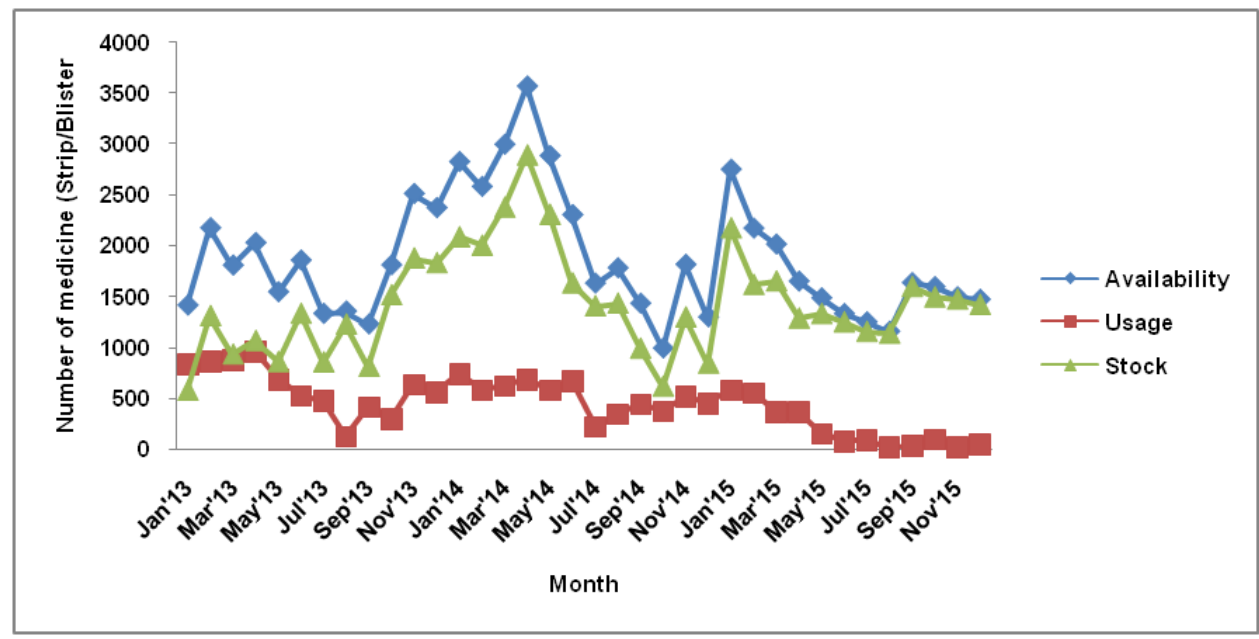

Fig. 2: Trend of the availability, usage, stock of nifedipine tab $10 \mathrm{mg}$

\section{Captopril tab $12.5 \mathrm{mg}$}

Captopril is one of the first choices drugs to treat the hypertension. This drug also available in primary health care. Its availability found increasing after NHI even fluctuated. The frequency of prescribe this drug was not different before and after NHI (fig. 3).

\section{Captopril tab 25 mg}

Fig. 4 showed that the usage of captopril tab $25 \mathrm{mg}$ increased after $\mathrm{NHI}$ implemented. The availability decreased in the first quarter $1 \mathrm{y}$ after NHI and became fluctuated and tend to be decreased in the second year of NHI. the trend of the stock of drug was similar with the availability.

\section{Amlodipine tab 5 mg}

Fig. 5 described that the availability and stock of amlodipine tab 5 increased significantly after NHI both first and second year NHI implementation. The drug used found grew up significantly after NHI. The important finding issue was the usage of amlodipine similar with the availability in the September 2014. Therefore, the stock of drug was zero.

\section{Amlodipine tab $10 \mathrm{mg}$}

Amlodipine tab $10 \mathrm{mg}$ also available in the first health care in metropolitan city Jakarta. This drug was not found before and the first year NHI because there is limitation of availability of this drug. The finding availability and stock of amlodipine tab $10 \mathrm{mg}$ tend to be increased each month. 


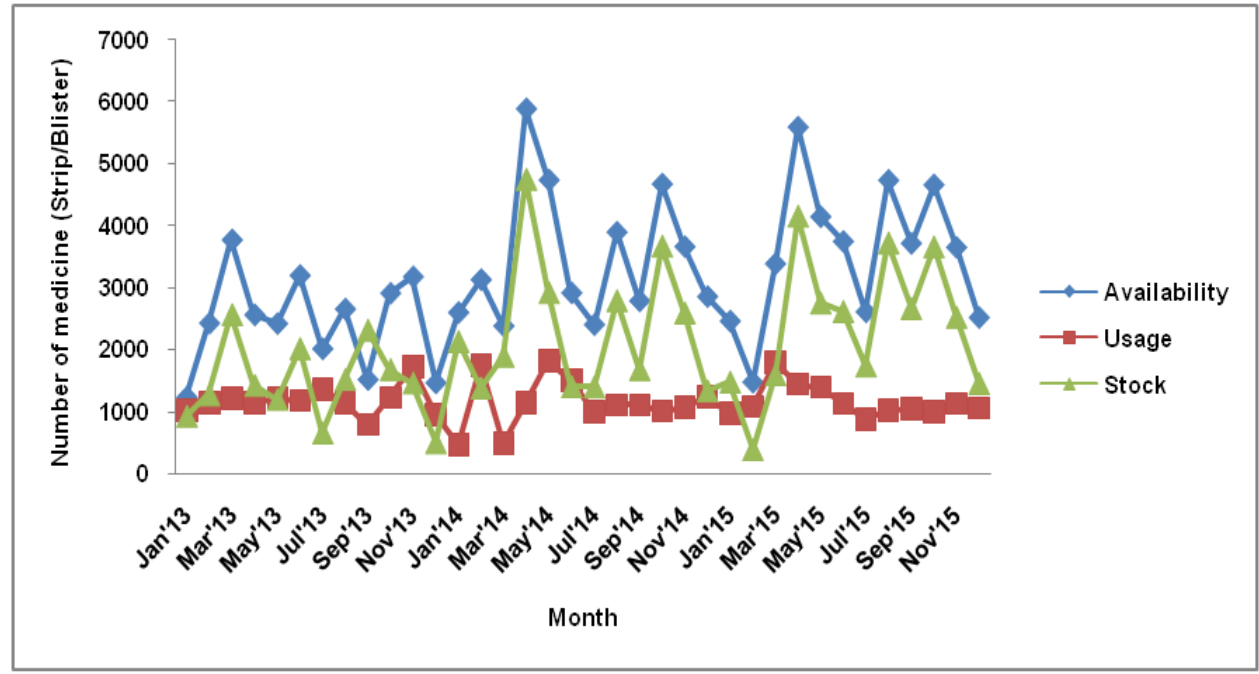

Fig. 3: Trend of the availability, usage, stock of captopril tab $12.5 \mathrm{mg}$

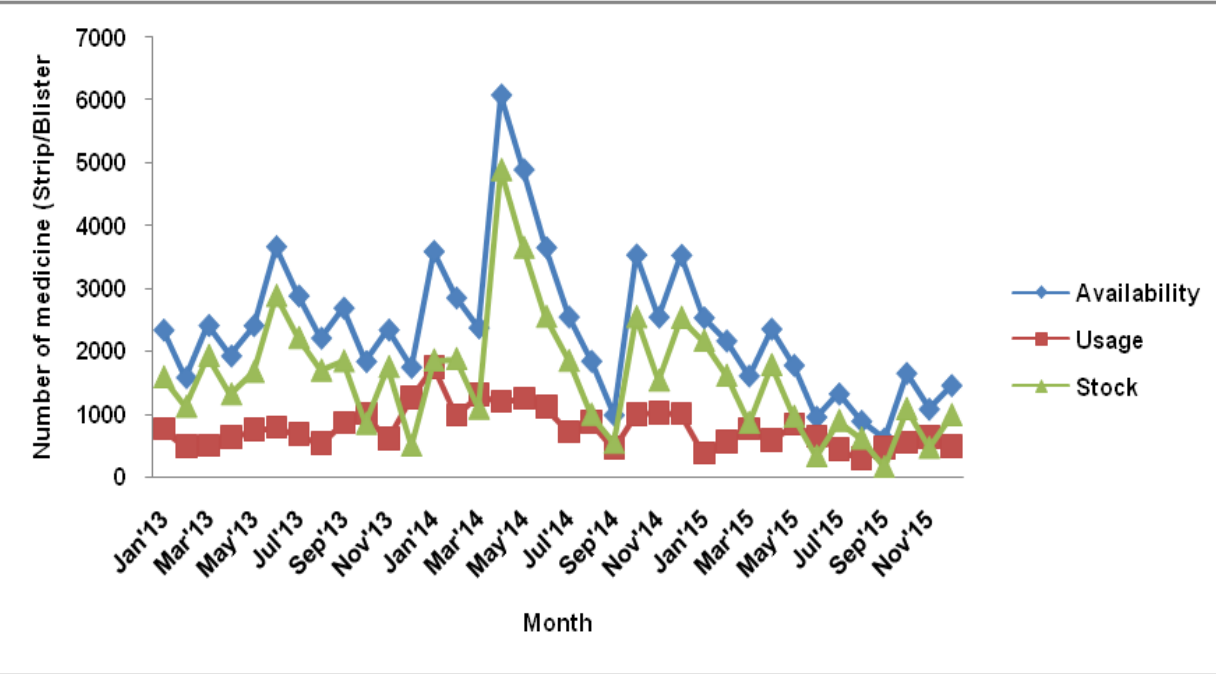

Fig. 4: The availability, drug used, and stock of drug of captopril tab 25 mg

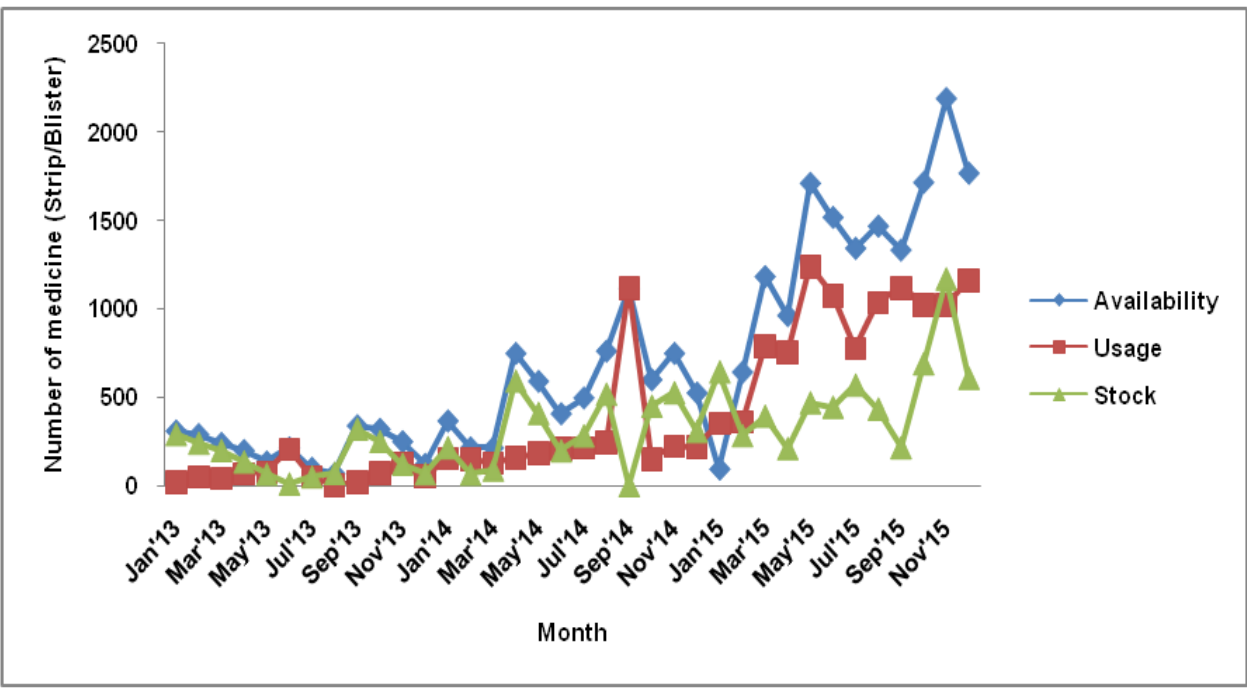

Fig. 5. Trend of the availability, usage, and stock of amlodipine tab $5 \mathrm{mg}$ 


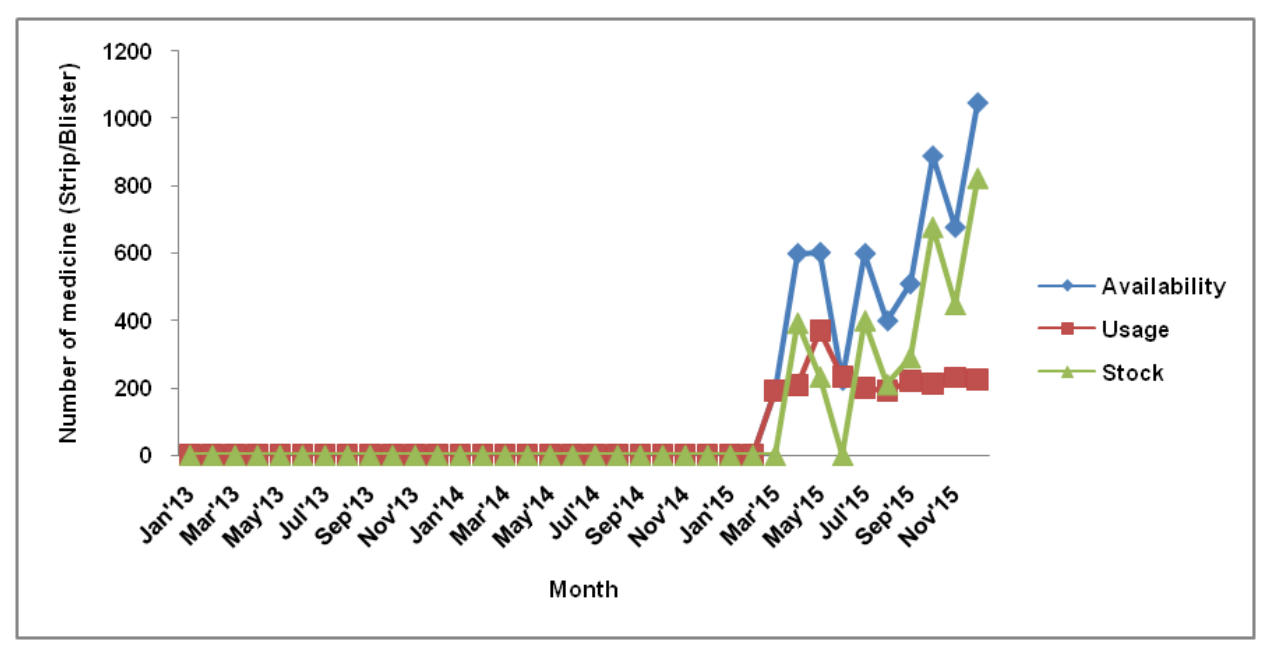

Fig. 6: Trend of the availability, usage, and stock of amlodipine tab $10 \mathrm{mg}$

\section{DISCUSSION}

There are 24 antihypertensive drugs enrolled in National Formulary [5]. These drugs are divided some dosage forms, such as tablet, film coated tablet, extended coated tablet, injection, infusion. In this study, we found $6(25 \%)$ kinds of antihypertensive drug available in National Formulary, such as amlodipine tab $5 \mathrm{mg}$ and $10 \mathrm{mg}$, hydrochlorothiazide tab $25 \mathrm{mg}$, captopril tab $12.5 \mathrm{mg}$ and $25 \mathrm{mg}$, nifedipine tab $10 \mathrm{mg}$. Furthermore, during period of study, antihypertensive medicine was found entirely generic and tablet dosage form. One of the reason was the rule of the government. The government (The Ministry of Health) asked the public health care centre used the generic drug [14]. Therefore, the primary health care centre as publich health care prescribed antihypertensive drug mostly generic. In African region, $68 \%$ patients in primary health care centers were prescribed generic medicine [15]. WHO recommended the generic medicine $100 \%$ in the health care center. Unfortunately, the generic medicine was prescribed very low in private than public healthcare centers $[16,17]$.

In era of NHI, The primary health care is the first place for the patient who use public insurance (NHI) should visit. Patients who had a serious health problem will rever to hospital that have better facilities. Therefore, only the selected drug was available in this place, mainly the first choice for hypertension [12]. All antihypertensive was found in this study were included the first choice for hypertention. The first choice antihypertensive by JNC 8 [12] and European Society of Hypertension (ESH) and the European Society of Cardiology (ESC) [13] were angiotensin converting enzyme (ACEI), such as captopril, Ca channel blocker (CCB) as amlodipine and nifedipine, and diuretic hydrochlorothiazide. However, Angiostensin Reseptor Blocker is the first choice for hypertension too; this medicine was not available in primary health care centre.

The availability of drug higher than the drug used, with estimated only 30\% drug used every year. The stock of drug in the end of the month became availability for the first next month. After NHI, the percentage drug used and availability increased due to the number of patients visit increased as well.

The demand of antihypertensive drug depend on the trend drug used. For example, hydrochlorothiazide was the highest available drug $1 \mathrm{y}$ before NHI. Unfortunately, the drug used less. Therefore, the percentage drug used and availability became down. The demand of this drug became lower in the first year of NHI.

The captopril and amlodipine were frequently prescribed due to the patients prefer to use it. The most frequency of antihypertensive drug used was captopril $12.5 \mathrm{mg}$ and $25 \mathrm{mg}$ and Nifedipine tab 10 $\mathrm{mg}$. These drugs were very popular among other antihypertensive drugs. One study in Spanish found that there is no different efficacy, side effect, and quality of life among patients using ACEIs and CCB in primary health care centre [18]. In China, the most frequency of antihypertensive used was CCB [19]. In another drug utilization study, 645 prescriptions were analyzed. A total of 697 antihypertensive drugs prescribed, of which $33.57 \%$ were ARBs, $16.79 \%$ ACEIs, $13.63 \%$ were BBs and $11.91 \%$ CCBs. About $32 \%$ of the antihypertensives prescribed were from the essential medicine list [20]. In Jordan, ACEI were the most commonly prescribed monotherapy [21]. Jarary et. al (2016) also found a similar result [22]. The different finding in Eastern Ethiopia, the most frequently prescribed class of antihypertensive drugs, was diuretics [23].

The implementation of NHI also had impact to the availability, stock of drug, and the usage of antihypertensive drug predominantly in the first year of NHI implemented. For example, the availability of amlodipine $5 \mathrm{mg}$ and $10 \mathrm{mg}$ tablet, captopril $12.5 \mathrm{mg}$ tablet increased significantly $(\mathrm{P}<0.05)$ after $\mathrm{NHI}$ was implemented. It was caused these drugs were the most frequency used. Moreover, hydrochlorothiazide decreased $(\mathrm{P}<0.05)$ as well due to the availability this drug was very high before NHI. The percentage medicine used compared the availability was very low. It was only $3 \%$. Therefore, the demand of this drug was limited after NHI. All stock of antihypertensive except captopril $25 \mathrm{mg}$ tab different significantly $(\mathrm{P}<0.05)$ after the application of NHI. Captopril $25 \mathrm{mg}$ tab was the most frequently prescribed in this study. The trend of availability, stock, and usage of this medicine was slightly increased but not different statistically. Therefore, the stock of medicine was persistent as well.

The finding medicine increased after NHI due to the number of patients who visited primary health care raised as well. The curiosity of citizen also supported the increase of drug. The government was not allowed patients to visit directly the second health care centre, such as hospital. Therefore the number of patients increased significantly in the first health care centre.

\section{CONCLUSION}

The availability and usage of amlodipine, hydrochlorothiazide, and captopril $12.5 \mathrm{mg}$ tab were significantly different after NHI. The usage of amlodipine, hydrochlorothiazide increased significantly but the consumed of nifedipine decreased. All stock of hypertensive drug except captopril $25 \mathrm{mg}$ tab changed significantly after NHI. This study clearly indicated $\mathrm{NHI}$ impacted to the availability, usage, and stock of antihypertensive drugs in the primary health care centre site in Indonesia.

\section{ACKNOWLEDGEMENT}

Authors gratefully acknowledge to Pancasila University to fund this study.

\section{FUNDING}

Funding from Pancasila University. 


\section{AUTHORS CONTRIBUTIONS}

All the authors have contributed equally.

\section{CONFLICT OF INTERESTS}

There are no conflicts of interest.

\section{REFERENCES}

1. JKN. National Health Insurance (JKN) in National Social Security System. Available from: http://jkn.kemkes.go.id. [Last accessed on 06 Oct 2020].

2. Ministry of Health. Regulation of $\mathrm{MoH}$ No. 27 about technical guideline INA-CBGs system. Jakarta; 2014.

3. Ministry of Health. The regulation of MoH No. 59 about standardize of rate of healthcare in the implementation of NHI. Jakarta; 2014.

4. PT ASKES. Price list and ceiling price of medicine. Jakarta; 2011.

5. Ministry of Health. National Formulary. No. HK.02.02/ MOH/1523/2015. Jakarta; 2015.

6. Presidential Decree. Indonesian presidential decree No. 111 changes of Indonesian presidential decree No. 12 Y 2013 about health insurance. Jakarta; 2013.

7. Servan Mori E, Heredia Pi I, Montañez Hernandez J. Access to medicines by seguro popular beneficiaries: pending tasks towards universal health coverage. PLoS One 2015;10:e0136823.

8. Mousnad MA, Ibrahim MIM, Palaian S, Shafie AA. Medicines utilization and trends in Sudan between 2006 and 2010. Trop J Pharm Res 2017;16:1717-28.

9. Jung YW, Pak H, Lee I, Kim EH. The effect of the diagnosisrelated group payment system on quality of care in the field of obstetrics and gynecology among Korean Tertiary Hospitals. Yonsei Med J 2018;59:539-45.

10. The regulation of ministry of health RI No. 63 y 2014. The procurement of drugs based on e-catalogue. Jakarta; 2014.

11. National health survey. Central data and information Ministry of Health the Republic of Indonesia. Jakarta; 2014.

12. James PA, Oparil S, Carter BL, Cushman WC, Dennison Himmelfarb C, Handler J, et al. Evidence-based guideline for the management of high blood pressure in adults: report from the panel members appointed to the Eighth Joint National Committee (JNC 8). Jama 2014;311:507-20.
13. Mancia G, Fagard R, Narkiewicz K, Redon J, Zanchetti A, Bohm $\mathrm{M}$, et al. ESH/ESC guidelines for the management of arterial hypertension: the task force for the management of arterial hypertension of the European Society of Hypertension (ESH) and of the European Society of Cardiology (ESC). Eur Heart J 2013;34:2159-219.

14. The regulation of Ministry of Health RI no. HK.02.02/ $\mathrm{MoH} / 068 / 1 / 2010$. The obligation of generic drugs used in the public health care facilities. Jakarta; 2010.

15. Ofori Asenso R, Brhlikova P, Pollock AM. Prescribing indicators at primary health care centers within the WHO African region: a systematic analysis (1995-2015). BMC Public Health 2016;16:724.

16. World Health Organization. The world medicines situation. Geneva: World Health Organization; 2004.

17. World Health Organization, Harvard Medical School and Harvard Pilgrim Health. Medicines use in primary care in developing and transitional countries Fact Book summarizing results from studies reported between 1990 and 2006. Geneva: World Health Organization; 2009.

18. Caceres MC, Moyano P, Farinas H, Cobaleda J, Pijierro A, Darado $\mathrm{P}$, et al. Trends in antihypertensive drug use in spanish primary health care 1990-2012. Adv Pharmacoepidemiol Drug Saf 2015;3:172.

19. Xu H, He Y, Xu L, Yan X, Dai H. The availability of Trends and patterns of five antihypertensive drug classes between 2007 and 2012 in China using hospital prescription data. Int J Clin Pharmacol Ther 2015;53:430-7.

20. Beg MA, Dutta S, Varma A, Kant R, Bawa S, Anjoom M, et al. Study on drug prescribing pattern in hypertensive patients in a tertiary care teaching hospital at Dehradun, Uttarakhand. Int J Med Sci Public Health 2014;3:922-6.

21. Al-Drabah E, Irshaid Y, Yasein N, Zmeili S. Prescription pattern of antihypertensive drugs in family practice Clinics at Jordan University Hospital. Med Sci 2013;2:469-88.

22. Jarari N, Rao N, Peela JR, Ellafi KA, Shakila S, Said AR, et al. A review on prescribing patterns of antihypertensive drugs. Clin Hypertens 2016;22:1-8.

23. Shukrala F, Gabriel T. Assessment of prescribing, dispensing, and patient use pattern of antihypertensive drugs for patients attending the outpatient department of hiwot fana specialized University Hospital, Harar, Eastern Ethiopia. Drug Des Dev Ther 2015;9:519-23. 